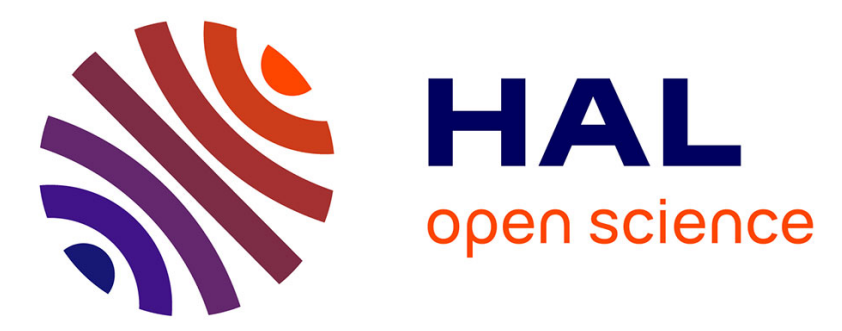

\title{
Consequences of shoaling of the Central American Seaway determined from modeling $\mathrm{Nd}$ isotopes
}

P. Sepulchre, T. Arsouze, Yannick Donnadieu, J.-C. Dutay, C. Jaramillo, J. Le Bras, E. Martin, C. Montes, A. Waite

\section{- To cite this version:}

P. Sepulchre, T. Arsouze, Yannick Donnadieu, J.-C. Dutay, C. Jaramillo, et al.. Consequences of shoaling of the Central American Seaway determined from modeling Nd isotopes. Paleoceanography, 2014, 29 (3), pp.176-189. 10.1002/2013PA002501 . hal-02902783

\section{HAL Id: hal-02902783 \\ https://hal.science/hal-02902783}

Submitted on 5 Jan 2021

HAL is a multi-disciplinary open access archive for the deposit and dissemination of scientific research documents, whether they are published or not. The documents may come from teaching and research institutions in France or abroad, or from public or private research centers.
L'archive ouverte pluridisciplinaire HAL, est destinée au dépôt et à la diffusion de documents scientifiques de niveau recherche, publiés ou non, émanant des établissements d'enseignement et de recherche français ou étrangers, des laboratoires publics ou privés. 


\section{Paleoceanography}

\section{RESEARCH ARTICLE}

10.1002/2013PA002501

\section{Key Points:}

- Model/data comparison of epsilon Nd suggests a shallow CAS during the Miocene

- CAS throughflow depends on seaway geometry and atmospheric coupling

- Ocean circulation responds nonlinearly to CAS shoaling

Correspondence to:

P. Sepulchre,

pierre.sepulchre@lsce.ipsl.fr

\section{Citation:}

Sepulchre, P., T. Arsouze, Y. Donnadieu, J.-C. Dutay, C. Jaramillo, J. Le Bras, E.

Martin, C. Montes, and A. J. Waite (2014), Consequences of shoaling of the

Central American Seaway determined from modeling $\mathrm{Nd}$ isotopes,

Paleoceanography, 29, 176-189, doi:10.1002/2013PA002501.

Received 8 MAY 2013

Accepted 11 DEC 2013

Accepted article online 17 DEC 2013

Published online 7 MAR 2014

\section{Consequences of shoaling of the Central American Seaway determined from modeling $\mathrm{Nd}$ isotopes}

\author{
P. Sepulchre ${ }^{1}$, T. Arsouze ${ }^{1,2}$, Y. Donnadieu ${ }^{1}$, J.-C. Dutay ${ }^{1}$, C. Jaramillo ${ }^{3}$, J. Le Bras ${ }^{1}$, E. Martin ${ }^{4}$, \\ C. Montes ${ }^{5}$, and A. J. Waite ${ }^{4}$ \\ ${ }^{1}$ Laboratoire des Sciences du Climat et de I'Environnement, CNRS-CEA-Université de Versailles Saint Quentin en Yvelines, \\ Gif-sur-Yvette, France, ${ }^{2}$ Now at Ecole Nationale Supérieure de Techniques Avancées, UME, Palaiseau, France, ${ }^{3}$ Smithsonian \\ Tropical Research Institute, Ancón, Panama, ${ }^{4}$ Department of Geological Sciences, University of Florida, Gainesville, Florida, \\ USA, ${ }^{5}$ Geociencias, Universidad de los Andes, Bogotá, Colombia
}

The Central American Seaway played a pivotal role in shaping global climate throughout the late Cenozoic. Recent geological surveys have provided new constraints on timing of the seaway shoaling, while neodymium isotopic $\left(\varepsilon_{\mathrm{Nd}}\right)$ data measured on fossil teeth, debris, and ferromanganese crusts have helped define the history of water masses in the region. Here we provide the first 3-D simulations of $\varepsilon_{\mathrm{Nd}}$ responses to the shoaling seaway. Our model suggests that a narrow and shallow seaway is sufficient to affect interoceanic circulation, that inflow/ outflow balance between the Caribbean and the Antilles responds nonlinearly to sill depth, and that a seaway narrower than $400 \mathrm{~km}$ is consistent with an active Atlantic meridional overturning circulation during the late Miocene. Simulated $\varepsilon_{N d}$ values in the Caribbean confirm that inputs from radiogenic Pacific waters in the Caribbean decrease as the seaway shoals. Despite model limitations, a comparison between our results and $\varepsilon_{\mathrm{Nd}}$ values recorded in the Caribbean helps constrain the depth of the Central American Seaway through time, and we infer that a depth between 50 and $200 \mathrm{~m}$ could have been reached $10 \mathrm{Ma}$ ago.

\section{Introduction}

The uplift and closure of the Central American Seaway (CAS, defined here as the seaway along the tectonic boundary between the South American plate and Panama microplate) is a critical event in Cenozoic biotic and climatic history. Connection between the two Americas allowed floral and faunal exchange starting in the Miocene [Kirby and MacFadden, 2005; Pennington and Dick, 2004; Weir et al., 2009, Jaramillo et al., in press] and culminating with the Great American Biotic Interchange [Webb, 2006] 2.6-2.7 Ma ago (hereafter Ma), merging terrestrial mammal communities that previously evolved on either side of the Panamanian isthmus [Leigh et al., 2013; MacFadden, 2006]. Theoretically, closure of the gateway between the Pacific and Atlantic Oceans likely had numerous climatic consequences, including reinforcement of Atlantic meridional overturning circulation (hereafter AMOC) and associated heat transport [Maier-Reimer et al., 1990]. However, the precise timing of the uplift and final closure of the isthmus, as well as the paleogeography of the region, have long been debated [Coates and Stallard, 2013; Molnar, 2008; Stone, 2013].

The first marked divergence between Caribbean and Pacific benthic foraminiferal faunas has been attributed to a thousand meter uplift of the sill between 12 and $10 \mathrm{Ma}$ [Duque-Caro, 1990], corresponding to the collision of the Central American volcanic arc and South America [Coates et al., 2004, Figure 8b] that shut off deepwater flow across the isthmus [Montes et al., 2012a, 2012b]. Shallow water exchange continued along segments of Panama north and south of the collision zone between Panama and South America until 3.5 Ma, when all communication ceased [Molnar, 2008, and references therein].

Recent geological field studies provide new constraints on the paleogeographic evolution of this region. Geologic mapping, as well as analytical data such as U/Pb geochronology of magmatic and detrital zircons, thermochronology, and paleomagnetic analyses [Montes et al., 2012a, 2012b], suggest that the Isthmus started to emerge in the middle Eocene and that by early Miocene times the Central American Seaway was constricted to $200 \mathrm{~km}$. These data combined with earlier studies [Kirby and MacFadden, 2005] also indicate that Central America, including the eastern part of the isthmus, had a continuous land connection to North America since the early Miocene. Tectonic closure, starting at $20 \mathrm{Ma}$ [Farris et al., 2011], would have hindered deep-water circulation soon after. Analogously, the complex collision zone of the Banda Arc with Australia, which took place during the late Neogene [Hall and Wilson, 2000; Harris, 1991], is characterized by multiple 
shallow-water gateways ( $<200 \mathrm{~m}$ deep), and one arc-parallel deeper-water passage (Timor Trough, $\sim 1200 \mathrm{~m}$ ) that effectively blocks circulation of warm south Pacific waters into the Indian Ocean [Jochum et al., 2009; Cane and Molnar, 2001].

In addition, growing studies of the isotopic composition of Neodymium isotopes $\left(\varepsilon_{\mathrm{Nd}}\right)$, a quasi-conservative tracer of water masses [Frank, 2002], provide unique information on the evolution of water exchange through the CAS during the last $20 \mathrm{Ma} . \varepsilon_{\mathrm{Nd}}$ values of waters from the Pacific and the Caribbean are highly distinct, and measurements made on fossil fish teeth and debris [Newkirk and Martin, 2009] and ferromanganese crusts [Frank et al., 1999; Reynolds et al., 1999] from both basins have been interpreted to show throughflow of Pacific into the Caribbean that started to decrease by the late Miocene. Despite numerous modeling studies (see section 3), there are ongoing questions regarding the interpretation of these data, and climate simulations with realistic paleogeographic constraints have been lacking. This is a concern because the extent of throughflow likely depends on the latitudinal position and orientation of the CAS. No study has yet addressed the behavior of the throughflow with a narrow, south-north oriented seaway, similar to the new model for the Miocene [Montes et al., 2012b]. Other key questions include the following: What is the relationship between sill-depth and water masses exchange through the seaway? Does the width of the seaway play a role in the throughflow and recorded $\varepsilon_{\mathrm{Nd}}$ values? Can model results provide new constraints to interpret the $\varepsilon_{\mathrm{Nd}}$ data and improve our understanding of the timing of CAS shoaling?

The present paper aims at answering some of these questions by reporting numerical simulations of $\varepsilon_{\mathrm{Nd}}$ values that take into account new geological constraints on CAS width and tests of the global climate response to different sill depths. Our aims are the following: (i) to provide the community with general circulation model (GCM) simulations forced by a configuration of the CAS different from previous hypotheses, (ii) to use actual coupled ocean-atmosphere dynamic constraints to help interpret the $\varepsilon_{\mathrm{Nd}}$ record, and (iii) to assess the capability of a direct model-proxy comparison to better constrain the chronology of CAS closure.

\subsection{Methods}

We use the Institut Pierre-Simon Laplace coupled ocean-atmosphere general circulation model (IPSLCM4) [Marti et al., 2009]. The atmospheric component is the LMDZ (Laboratoire de Météorologie Dynamique) model [Hourdin et al., 2006], which is run at a longitude-latitude resolution of $3.75^{\circ} \times 2.5^{\circ}$ with 19 vertical layers. The soil-vegetation component is based on ORCHIDEE [Krinner, 2005], which describes the processes of water and energy exchange between the biosphere and the atmosphere, as well as a routing scheme for water in soils. The ocean component is the OPA8.2 system, which is based on the primitive equations of global and regional ocean circulation [Madec and Imbard, 1996]. There is no flux correction in the coupling, which has been shown to be crucial to improve the reliability of coupled processes, and to avoid multiple steady states [Dijkstra and Neelin, 1995].

The ocean grid is based on a $2^{\circ}$ Mercator mesh, with a $1^{\circ}(\sim 110 \mathrm{~km})$ latitudinal resolution refinement near the equator. The mesh is tripolar, with two poles set on continents in the Northern Hemisphere in order to avoid numerical instabilities and filtering at high latitudes and ensure an anisotropy ratio of 1 almost everywhere. As described in Swingedouw et al. [2007], vertical eddy diffusivity (Kz) and viscosity coefficients are computed from a 1.5 turbulent closure scheme based on a prognostic equation for the turbulent kinetic energy [Blanke and Delecluse, 1993]. A minimum of $0.1 \mathrm{~cm}^{2} \cdot \mathrm{s}^{-1}$ is imposed on the computed $K z$. This value is reached in almost all of the deep ocean, except in the case of static instability when both diffusivity and viscosity coefficients are increased to $100 \mathrm{~m}^{2} \mathrm{~s}^{-1}$. The free surface formulation of Roullet and Madec [2000] is used to ensure salt conservation. Since the typical scale of eddies $(50 \mathrm{~km})$ is much smaller than grid resolution, their impact must be parameterized using the Gent and McWilliams [1990] parameterization of velocity with a coefficient that depends on the growth rate of baroclinic instabilities (varying from 15 to $3000 \mathrm{~m}^{2} \mathrm{~s}^{-1}$ ). The eddy viscosity coefficient of momentum depends on the geographical position. It is taken as $40,000 \mathrm{~m}^{2} \mathrm{~s}^{-1}$, reduced to $2000 \mathrm{~m}^{2} \mathrm{~s}^{-1}$ in the equator regions except near the western boundaries. Lateral diffusion acts along the isopycnal surfaces and the eddy diffusivity coefficient is uniform at $2000 \mathrm{~m}^{2} \mathrm{~s}^{-1}$.

The IPSLCM4 model has been widely used in intercomparison studies within the Paleoclimate Modelling Intercomparison Project framework [Braconnot et al., 2007] and for the Fourth Assessment Report of the Intergovernmental Panel on Climate Change report [e.g., Arzel et al., 2006]. Here we present only a few key characteristics of the model that are critical for this study. The model performs well in the tropics for both 

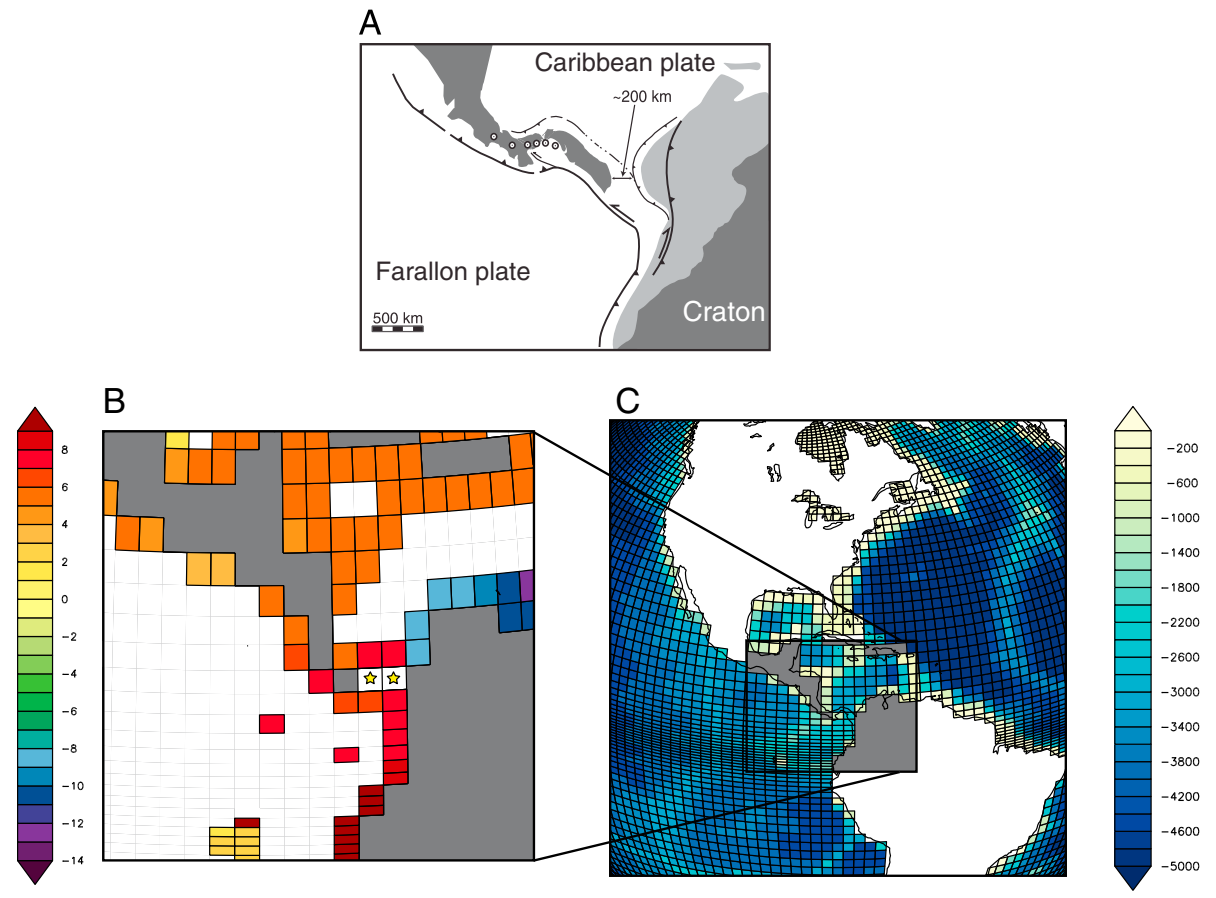

Figure 1. (a) Paleogeographic reconstruction of the region of interest during the early Miocene suggesting a narrow ( 200 km) Central American Seaway. Modified from Montes et al. [2012a]. (b) Marginal $\varepsilon_{\text {Nd }}$ values in the CAS region (left) interpolated from [Jeandel et al., 2007] and used as boundary conditions for model simulations. The yellow stars indicate two open gridpoints that provide the best representation of isthmus reconstruction from [Montes et al., 2012a] (c) Bathymetry (meters) for the CAS region projected on the IPSLCM4 $2^{\circ}$ grid.

seasonal and interannual variability, and El Niño-Southern Oscillation amplitude [Marti et al., 2009]. Sea surface temperature biases do not exceed $1{ }^{\circ} \mathrm{C}$ in the Caribbean Sea. Sea ice extent is correctly simulated, with a small eastward extent bias east of Greenland, linked to the eastward shift of the convection sites [Swingedouw et al., 2007]. However, the simulated AMOC, with maximum values of about 11-12 Sv, places IPSLCM4 among the coupled GCMs that simulate the lowest values in the IPCC AR4 report [Schneider et al., 2007] and reflects the underestimation of the ocean meridional heat transport. This bias is mainly due to the atmospheric component, as atmospheric westerlies are shifted equatorward and prevent a strong ocean circulation, salt transport, and deep convection in the Labrador Sea [Marti et al., 2009]. A second factor is a strong bias in the E - P (Evaporation minus Precipitation) budget between $45^{\circ} \mathrm{N}$ and $50^{\circ} \mathrm{N}$, with overestimated precipitation and underestimated evaporation, ultimately decreasing the sea surface salinity at this location.

Montes et al. [2012a, 2012b] suggest that a long peninsula connecting Panama to North America was above sea level since the early Miocene (ca. 23-17 Ma) and that the CAS was already reduced to a narrow seaway of $200 \mathrm{~km}$ (Figure 1a) at that time. Here we modified the $2^{\circ}$ bathymetry of our model to account for these geological constraints. The best trade-off between these data, the model resolution, and the limitation of having at least two grid boxes to represent ocean dynamics in the seaway, is a ca. $400 \mathrm{~km}$ longitudinal opening at $\sim 8^{\circ} \mathrm{N}$ (Figures $1 \mathrm{~b}$ and $1 \mathrm{c}$ ). We performed a control (CTL) experiment with present-day bathymetry, greenhouse gases concentrations, and insolation (Table 1), and an open-isthmus experiment (CAS2700) with the modified paleogeography described above and a sill depth set at $2700 \mathrm{~m}$ below sea level. The control simulation was run for 770 years and CAS2700 was integrated for 1000 years. Results are presented as 100 year averaged climatologies made after 670 years of run time. This experiment is characterized by a typical AMOC, with an overturning index averaging $11 \cdot 10^{6} \mathrm{~m}^{3} . \mathrm{s}^{-1}$ (i.e., 11 Sverdrups, hereafter Sv), a value that is in the range of fully coupled GCMs used in the last IPCC AR4 report [Schneider et al., 2007]. Having constrained the CAS width, we aimed to test the response of the global climate system to CAS depth by performing simulations with the same horizontal configuration but with sills ranging from $2700 \mathrm{~m}$ to $50 \mathrm{~m}$. A simulation with a $500 \mathrm{~m}$ sill (CAS500) was integrated for 400 years, starting from the equilibrated CAS2700. In turn we used the equilibrium of CAS500 to initiate simulations with shallower sills, at $200 \mathrm{~m}$ (CAS200) and $50 \mathrm{~m}$ (CAS50), respectively, which were each run for an additional 300 years. 


\begin{tabular}{|c|c|c|c|c|c|c|c|c|c|c|}
\hline Experiments & $\begin{array}{l}\text { Boundary } \\
\text { Conditions }\end{array}$ & $\begin{array}{c}\text { Initial } \\
\text { State of the } \\
\text { Ocean }\end{array}$ & $\begin{array}{l}\text { Simulation } \\
\text { Length } \\
\text { (years) }\end{array}$ & $\begin{array}{l}\varepsilon_{\mathrm{Nd}} \\
\text { Simulation } \\
\text { Length }\end{array}$ & $\begin{array}{l}\text { Seaway } \\
\text { Width } \\
(\mathrm{km})\end{array}$ & $\begin{array}{l}\text { Seaway } \\
\text { Depth } \\
(\mathrm{m})\end{array}$ & $\begin{array}{l}\text { AMOC } \\
\text { Index } \\
\text { (Sv) }\end{array}$ & $\begin{array}{c}\text { Eastward Volume } \\
\text { Transport } \\
\text { in CAS (Sv) }\end{array}$ & $\begin{array}{c}\text { Westward } \\
\text { Volume Transport } \\
\text { in CAS (Sv) }\end{array}$ & $\begin{array}{l}\text { Simulated } \\
\text { eNd in the } \\
\text { Caribbean }\end{array}$ \\
\hline CTL & & $\begin{array}{r}\text { Levitus (1982) } \\
\text { climatology }\end{array}$ & 770 & & Closed & Closed & 11.6 & - & - & -5.9 \\
\hline CAS2700 & pCO2: 348 & $\begin{array}{r}\text { Levitus (1982) } \\
\text { climatology }\end{array}$ & 1000 & 4000 & & 2768 & 2.4 & 14.9 & 7.3 & -2.1 \\
\hline CAS500 & $\begin{array}{l}\text { modern orbital } \\
\text { parameters }\end{array}$ & $\begin{array}{c}\text { Equilibrated } \\
\text { CAS2700 }\end{array}$ & 400 & & 400 & 512 & 3.9 & 12 & 5.9 & -2.6 \\
\hline CAS200 & & $\begin{array}{c}\text { Equilibrated } \\
\text { CAS500 }\end{array}$ & 300 & & & 217 & 4.4 & 6.4 & 4.4 & -3.5 \\
\hline CAS50 & & $\begin{array}{c}\text { Equilibrated } \\
\text { CAS500 }\end{array}$ & 300 & & & 55 & 2.5 & 0.09 & 3.5 & -5.2 \\
\hline
\end{tabular}

We used equilibrated oceanic dynamical climatologies from our IPSLCM4 experiments to simulate offline the $\mathrm{Nd}$ isotopic composition following the approach proposed by Arsouze et al. [2007], that provides successful results for both modern and past climate $\varepsilon_{\mathrm{Nd}}$ simulations [Arsouze et al., 2007; Arsouze et al., 2008]. Nd concentrations observed in the modern open ocean range from 15 to $35 \mathrm{pmol} / \mathrm{kg}$ [Lacan et al., 2012]. As a first approach, we held the $\mathrm{Nd}$ concentration constant, and only modeled variations in $\mathrm{Nd}$ isotopic compositions, described as $\varepsilon_{\mathrm{Nd}}$. More advanced modeling studies including both $\mathrm{Nd}$ concentration and isotopic composition have already been performed for the modern ocean [Arsouze et al., 2009; Grenier et al., 2013; Jones et al., 2008; Rempfer et al., 2011; Siddall et al., 2008], but the required set up is more complex (for example, one needs marine particle fields generated by biogeochemical models that are not available in IPSLCM4). More importantly, such an approach involves more uncertainties related to modern and past variations of sources and therefore is not relevant within the framework of a bathymetry change sensitivity case study. Here $\varepsilon_{\mathrm{Nd}}$ is treated as a passive conservative tracer in the ocean and is implemented in an " off-line " transport model (using the 100 years climatological fields averaged after 670 years of simulation), where it follows the classical transport equation:

$$
\frac{\partial \varepsilon_{\mathrm{Nd}}}{\partial t}=S\left(\varepsilon_{\mathrm{Nd}}\right)-U \cdot \nabla \varepsilon_{\mathrm{Nd}}+\nabla \cdot\left(K \nabla \varepsilon_{\mathrm{Nd}}\right)
$$

where $S\left(\varepsilon_{\mathrm{Nd}}\right)$ is the source minus sink (SMS) term, the second and last right-hand terms are the three-dimensional advection and both lateral and vertical diffusion of $\varepsilon_{\mathrm{Nd}}$, respectively. The boundary exchange (BE) process is considered as the main source of Nd into the ocean [Arsouze et al., 2007] and therefore is the only SMS term taken into account here. It is parameterized by a relaxing equation that restores the initial $\varepsilon_{\mathrm{Nd}}$ signature of a water mass entering in contact with any margin toward the value of this margin:

$$
S\left(\varepsilon_{\mathrm{Nd}}\right)=1 /{ }_{\tau} \cdot\left(\varepsilon_{\mathrm{Nd}} \text { argin }-\varepsilon_{\mathrm{Nd}}\right) \cdot \text { mask }_{\mathrm{m} \text { argin }}
$$

where $\tau$ is the characteristic relaxing time of $\mathrm{BE}, \varepsilon_{\mathrm{Nd}}$ margin

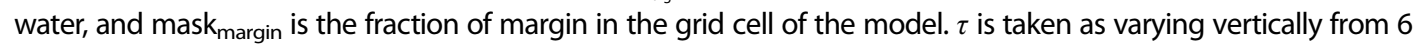
months at the surface, to 10 years at depth, as this parameterization gives the best results for previous simulations [Arsouze et al., 2007]. mask margin $_{\text {in }}$ denotes the proportion of surface in the grid where BE process effectively occurs, and has been estimated from the high-resolution bathymetry ETOPO-2 with values ranging between 0 and 1 . The depth limit for BE on the margin has been chosen at $3000 \mathrm{~m}$ depth [Boillot and Coulon, 1998]. All off-line simulations are initialized with a uniform $\varepsilon_{\mathrm{Nd}}$ and run for 4000 years.

\section{Results}

\subsection{IPSLCM4 Response to an Open CAS Compared to Other Models}

Since the early 1990s, more than 20 climate modeling experiments have been carried out to quantify the impact of an open CAS on climate [e.g., Fedorov et al., 2013; Klocker et al., 2005; Lunt et al., 2008; Maier-Reimer et al., 1990; Mikolajewicz and Crowley, 1997; Mikolajewicz et al., 1993; Motoi et al., 2005; Murdock et al., 1997; Nisancioglu et al., 2003; Prange and Schulz, 2004; Schneider and Schmittner, 2006; Steph et al., 2006, 2010; von der Heydt and Dijkstra, 2005; 2006; Zhang et al., 2012]. Quantitative comparison of the results of these studies is difficult because of (i) the diversity of models used (from Ocean models forced by present-day atmospheric fields, to Earth system Models of Intermediate Complexity (EMICs), to fully coupled GCMs) and diverging 


\section{QAGU Paleoceanography}

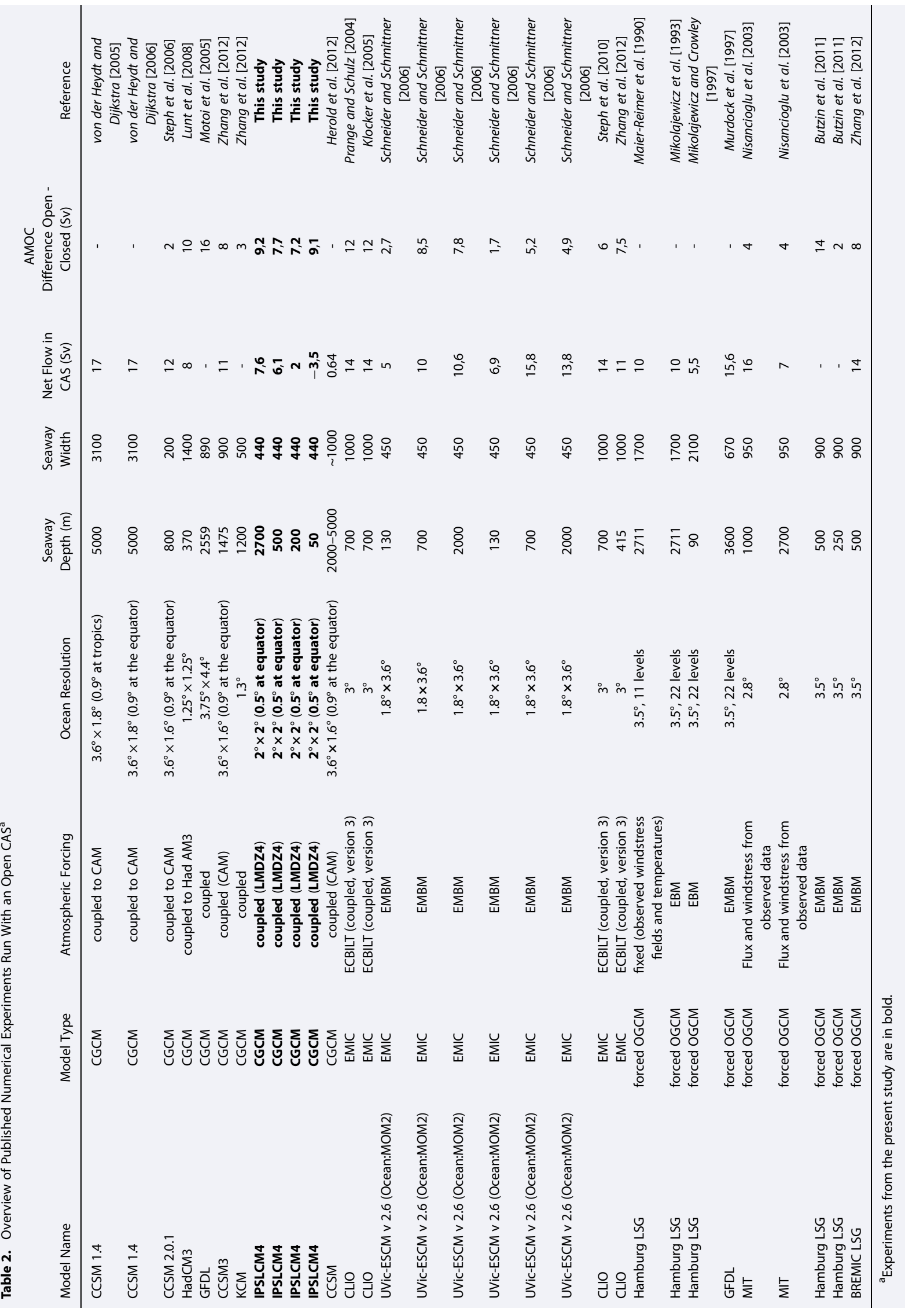




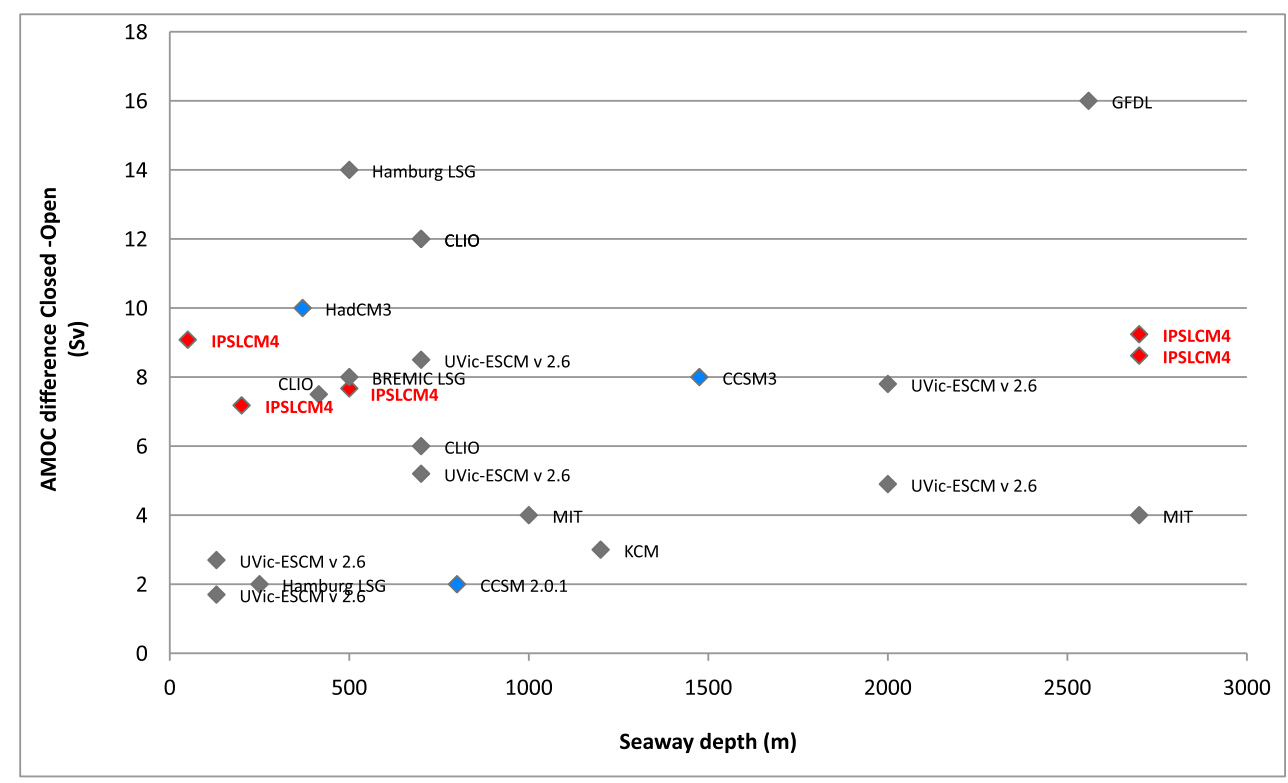

Figure 2. Response of AMOC to opening of CAS to prescribed depths in various climate models, as quantified by the AMOC index anomaly between closed and open experiments. Results from this study are highlighted in red.

resolutions, parameterizations and boundary conditions, and (ii) the multiplicity of open CAS configurations, with width varying from ca. $3000 \mathrm{~km}$ to $200 \mathrm{~km}$, and depth varying from 50 to $5000 \mathrm{~m}$. In 2012, Zhang et al. ran the first intercomparison study among seven different climate models, focusing on Atlantic Meridional Overturning Circulation (AMOC) and equatorial Pacific thermocline changes with an open seaway. Here we have computed (Table 2) these results together with earlier studies and analyzed how IPSLCM4 behaves compared to other models, with a focus on fully coupled GCMs (i.e., those including interaction between ocean and atmosphere).

Although climate models all simulate a decrease of AMOC intensity when an open CAS is prescribed (as indicated by positive values in Figure 2), responses as a function of CAS depth amongst models are scattered. In our case, the simulated $A M O C$ decrease for seaway depths ranging from $200 \mathrm{~m}$ to $2700 \mathrm{~m}$ are comparable to other CGCMs such as CCSM3 and HadCM3 (Figure 2). Still, absolute values ranging from 2.4 to $4.4 \mathrm{~Sv}$ indicate very weak AMOC activity and a nonlinear relationship with CAS depth. Interestingly, the shallow isthmus $(50 \mathrm{~m})$ experiment also shows a strong AMOC decrease, although the dynamical mechanisms involved are different from deep-open cases (see section 3.2). Open-isthmus experiments also provide a deeper thermocline ( $+20 \mathrm{~m}$ averaged over the region $150^{\circ} \mathrm{W}-90^{\circ} \mathrm{W}, 5^{\circ} \mathrm{N}-5^{\circ} \mathrm{S}$, not shown) in the eastern tropical Pacific, a result consistent with CGCMs results presented in Zhang et al. [2012].

\subsection{Caribbean Dynamics With Various CAS Depths}

The CTL experiment depicts a total inflow in the Caribbean Sea of $18.3 \mathrm{~Sv}$ through the passage south of the Greater Antilles, and an outflow of the same value (modulo Evaporation-Precipitation + Runoff balance) in the Florida Strait (Figures 3a and 3e). These values are below data estimates of 28 Sv [Johns et al., 2002]. This underestimation is likely linked to the slow AMOC, but also to the coarse resolution of our model, that prevents accurate representation of the actual geography of the Antilles Arc and associated passages, especially the windward passage that is supposed to add an inflow of 3 to 9 Sv to the Caribbean [Johns et al., 2002].

The deep opening of the seaway generates a third pathway for Caribbean waters, with a surface branch of the inflow being driven westward by surface winds into the open CAS and ultimately into the equatorial Pacific (Figure 3b), leading to a westward volume transport of $7.2 \mathrm{~Sv}$ between the surface and $120 \mathrm{~m}$. This result is consistent with previous fully coupled simulations [Lunt et al., 2008], but differs from other studies [Nisancioglu et al., 2003; Schneider and Schmittner, 2006] that suggest eastward flow over the entire water column as a response to the interoceanic steric height gradient. These differences can be linked to the absence of full-dynamical ocean-atmosphere coupling in the latter studies, which prevents the positioning of strong surface winds over the seaway that drive surface flow. At intermediate depths, the circulation through 
A CTL_Surface

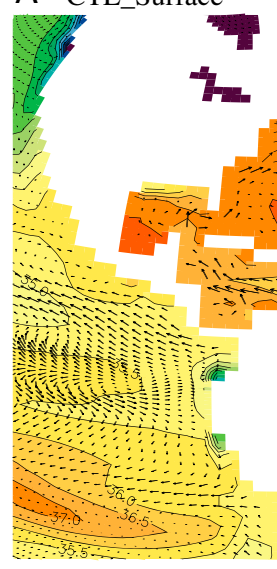

C CTL_500m
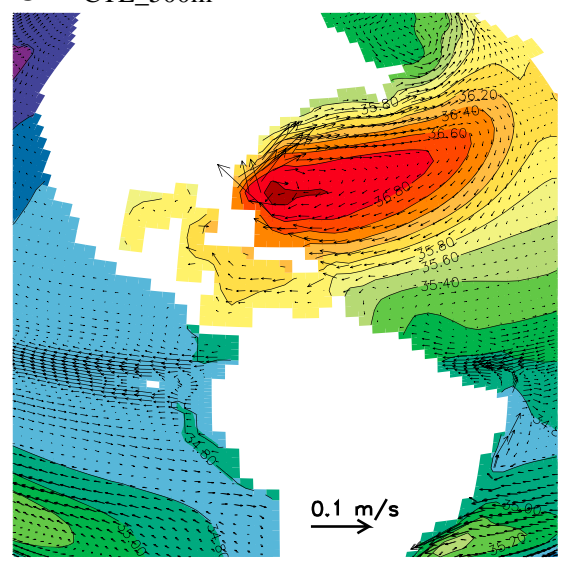

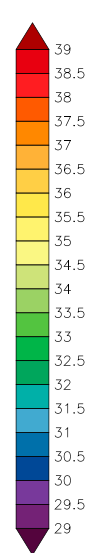

B CAS2700_Surface

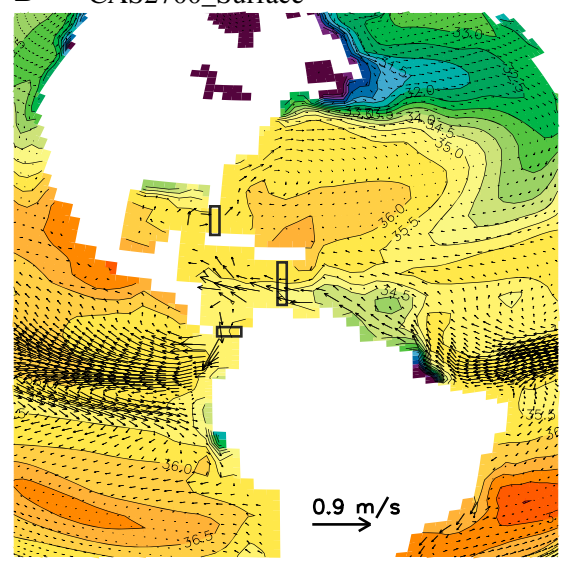

\section{CAS2700_500m}

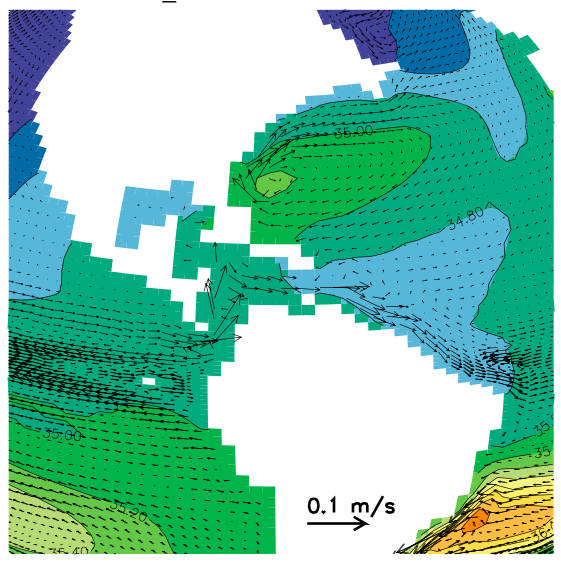

E

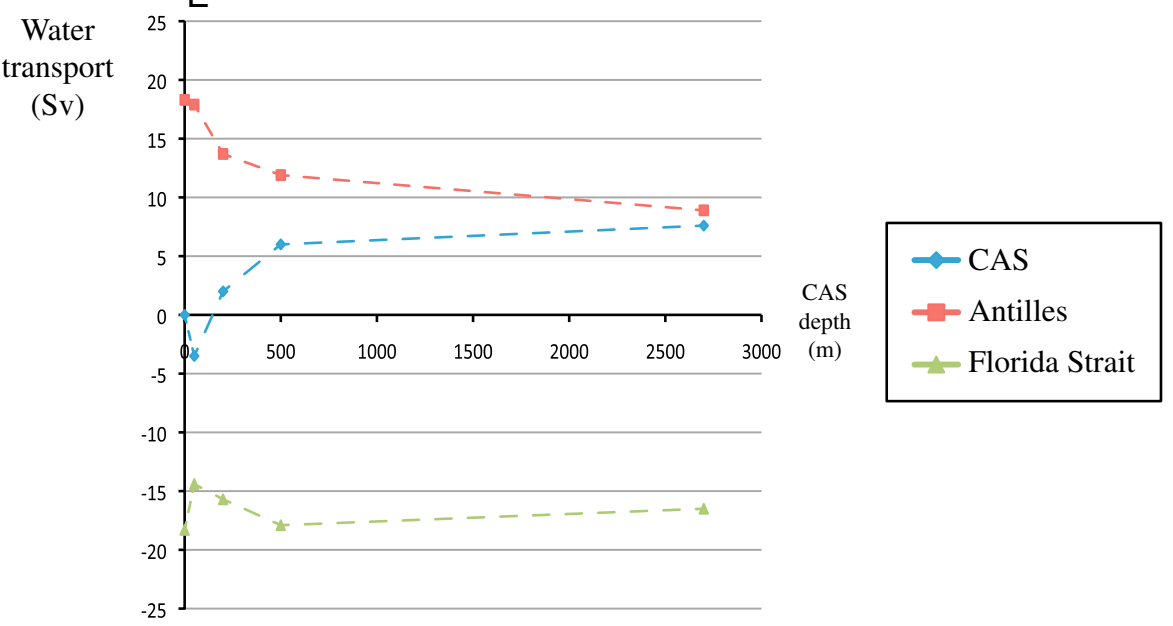

Figure 3. (a and c) Simulated annual salinity (contours) and current speed (arrows) for CTL and (b and d) CAS2700 experiments at surface (Figures $3 \mathrm{a}$ and $\mathrm{3b}$ ) and $500 \mathrm{~m}$ (Figures $3 \mathrm{c}$ and $3 \mathrm{~d}$ ). E. Water fluxes (Sv) as a function of CAS depth prescribed in the five simulations and computed in the three Caribbean region gateways, namely, the Florida Strait, the Antilles, and the CAS (indicated by black rectangles on Figure 3b). Positive (negative) values indicate inflow to (outflow from) the Caribbean.

the seaway is reversed (Figures $3 \mathrm{c}$ and $3 \mathrm{~d}$ and Figure $4 \mathrm{a}$ ), and the eastward volume transport amounts to $14.8 \mathrm{~Sv}$. Thus, the overall net (i.e., integrated over the entire column) volume transport is $7.6 \mathrm{~Sv}$ and directed from the Pacific to the Atlantic. In every open-isthmus experiment except CAS50, an extension of the Pacific Equatorial Under Current (hereafter EUC) reaches the Colombian coast north of the equator, crosses the CAS 
A

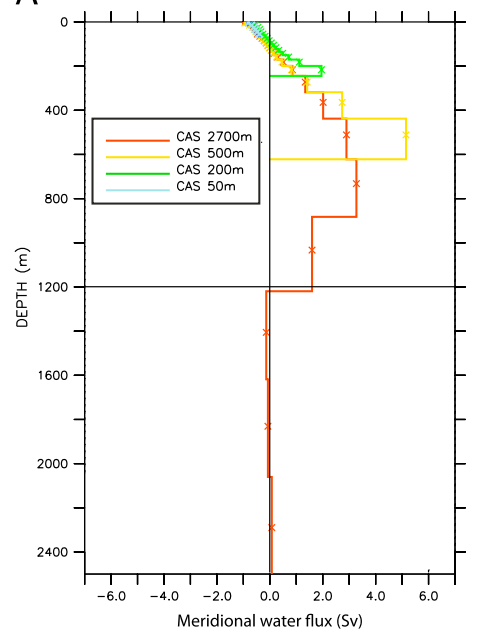

B

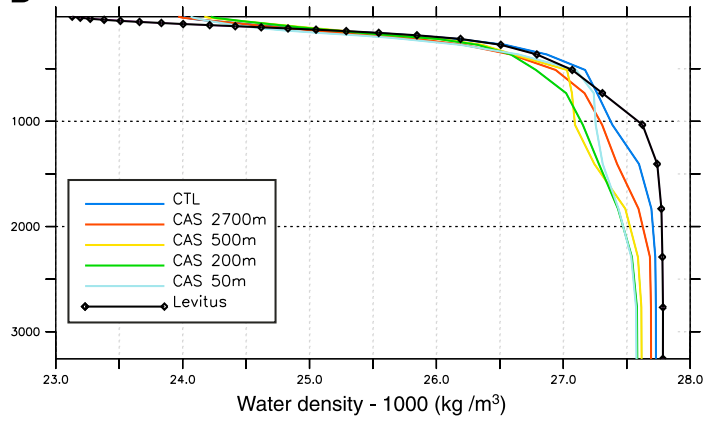

Figure 4. (a) Vertical profile of meridional water transport (Sv) through the CAS for the 4 open-isthmus experiments. Positive values indicate northward transport from the Pacific to the Caribbean. (b) Vertical profile of water density averaged over the Caribbean.

between 100 and $500 \mathrm{~m}$ deep, and flows into the tropical Atlantic following the South American coast, a result consistent with earlier numerical experiments [e.g., Butzin et al., 2011]. In CAS2700 this throughflow occurs down to $1000 \mathrm{~m}$ with almost no interoceanic exchange below this depth. The eastward CAS throughflow causes the Antilles input to drop to 8.9 Sv (Figure 3e). The balance between CAS and Antilles throughflows varies nonlinearly as the sill shoals, indicating a threshold, between 500 and $200 \mathrm{~m}$ that determines whether the Atlantic or Pacific is the primary source of Caribbean waters. Invasion of Pacific waters into the Caribbean, and ultimately into the Atlantic through the Florida Strait and into the Atlantic gyre, dramatically reduces Atlantic salinity and the AMOC, a result consistent with most coupled GCM responses to CAS opening (Table 1). When the seaway depth is set at $50 \mathrm{~m}$, the net CAS throughflow is reversed $(-3.5 \mathrm{~Sv})$, with wind-driven surface waters flowing westward, and no counter-current entering the seaway. Interestingly, this mechanism does not allow an AMOC increase, as it leads to an escape of Atlantic salty waters into the Pacific, thereby slowing Atlantic meridional transport and associated deep convection at high latitudes.

The vertical profile of density (Figure 4b) averaged over the Caribbean shows a highly stratified water column with rapidly increasing density down to $500 \mathrm{~m}$ depth in all experiments, which strongly limits vertical mixing between the subsurface and deep waters. Changes in the density gradient between 500 and $1000 \mathrm{~m}$ indicate weak vertical mixing, while density is relatively constant below $1000 \mathrm{~m}$. Surprisingly, the vertical pattern of stratification, which remains unchanged when CAS is open, does not indicate strong sinking of Pacific waters in the Caribbean. This result is likely linked to processes that are not accounted for in our model; indeed we acknowledge two limitations of our model for the Caribbean basin. First, the resolution of the ocean grid causes the Caribbean subbasins to be fully separated at depth (not shown), thereby reducing horizontal fluxes between them. Second, modeling sill overflows is particularly difficult, as it relies on eddy processes and requires fine vertical discretization and parameterization [Griffies et al., 2000]. Thus, although the CTL density profile compares quite well with Levitus climatologies (Figure 4b), the deepwater overflow through the CAS and vertical mixing in the Caribbean could be underestimated. These two limitations have consequences on simulated $\varepsilon_{\mathrm{Nd}}$ values, as described in the following paragraph.

\subsection{Response of $\varepsilon_{\mathrm{Nd}}$ to Opening of the CAS}

At the global-scale, CTL simulated values for surface (not shown) and deep-ocean $\varepsilon_{\text {Nd }}$ (Figure $5 a$ ) are consistent with observations [Lacan et al., 2012], and display the interoceanic gradient between the Pacific and Atlantic. This gradient is linked to the isotopic signatures of the margins that are very radiogenic in the Pacific and very nonradiogenic, especially at high latitudes, in the Atlantic [Jeandel et al., 2007]. The $\varepsilon_{\mathrm{Nd}}$ vertical profile in the Caribbean shows CTL values increasing with depth, from -7.5 at surface to +0.5 at $3000 \mathrm{~m}$ (Figure 5b). There are no published deepwater modern instrumental measurements of $\varepsilon_{\mathrm{Nd}}$ in the Caribbean, but modern values are expected to be close to -11 [Frank et al., 2006], which would suggest our model overestimates radiogenic values at depth. This bias is linked to the particular configuration of the Caribbean 

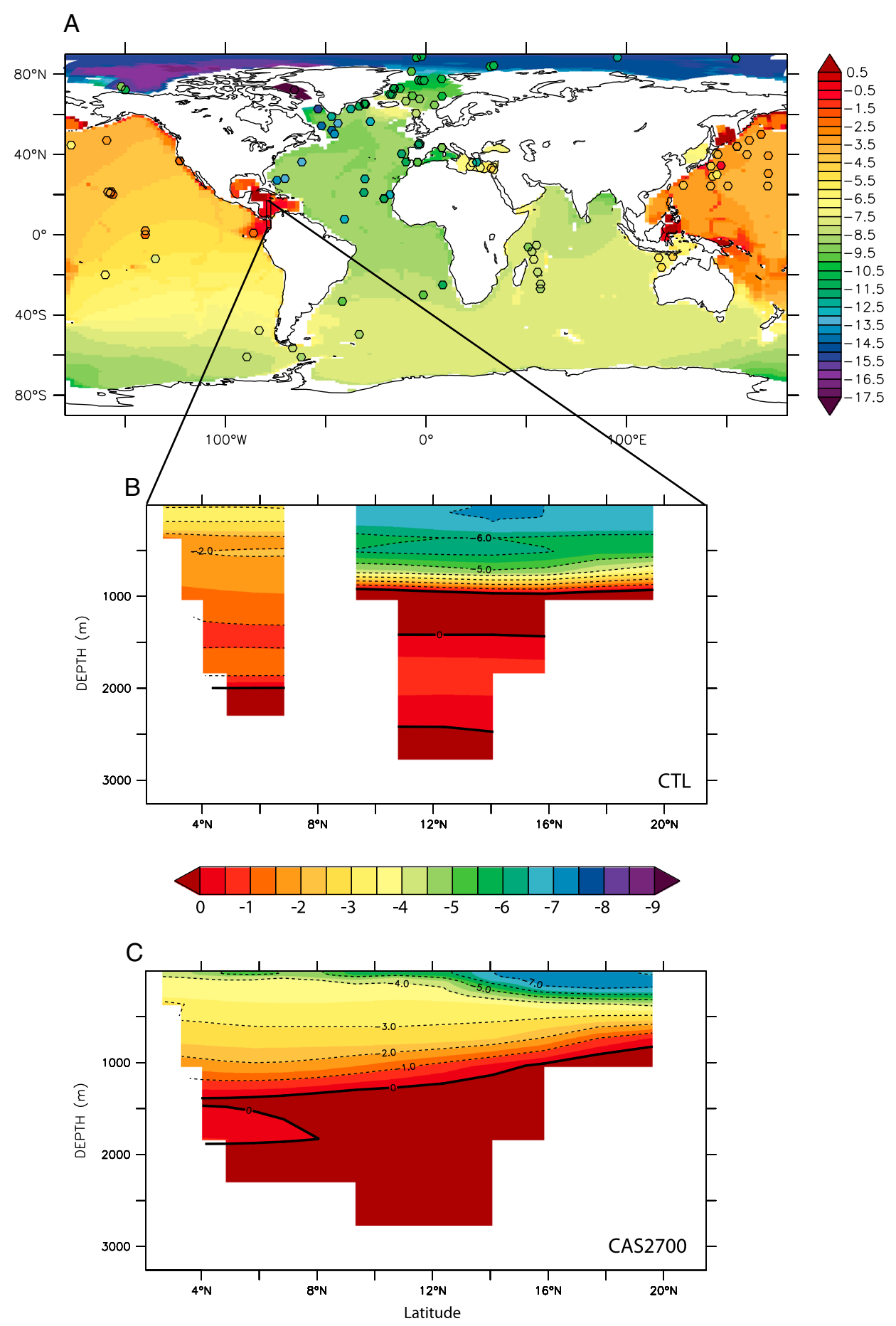

Figure 5. (a) Simulated $\varepsilon_{\mathrm{Nd}}$ ( $\varepsilon_{\mathrm{Nd}}$ units) for the CTL experiment, averaged between $800 \mathrm{~m}$ and the seafloor. Circles represent modern data from Lacan et al. [2012]. (b and c) Latitude/Depth profiles of simulated $\varepsilon_{\mathrm{Nd}}$ across $83^{\circ} \mathrm{W}$, for CTL (Figure 5b) and CAS2700 experiments (Figure 5c).

in our model, in which the Caribbean behaves as a closed sea with declining horizontal velocity as a function of depth. As a result, $\varepsilon_{\mathrm{Nd}}$ values increase toward positive margin values (Figure 1) due to boundary exchange. Together with model limitations expressed earlier, this enhanced boundary exchange yields artificially high deepwater $\varepsilon_{\mathrm{Nd}}$ values in the Caribbean. Conversely, $\varepsilon_{\mathrm{Nd}}$ values simulated at intermediate depth in the Caribbean appear more in line with paleomeasurements [Newkirk and Martin, 2009]. As there is no clear physical mechanism to explain overflow of deepwater masses over shallow sills such as the Antilles, and as 
A

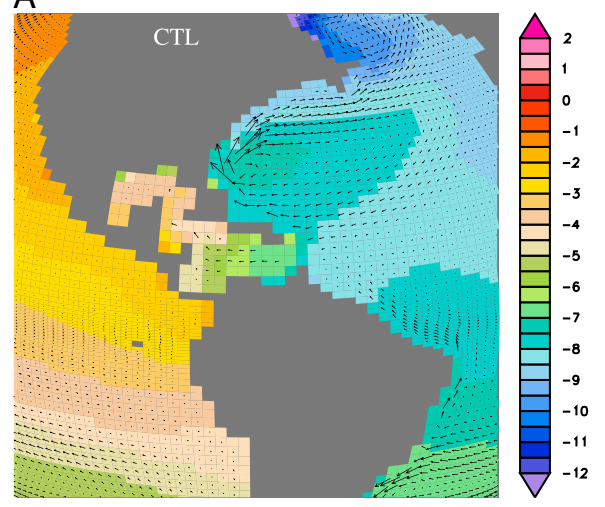

B

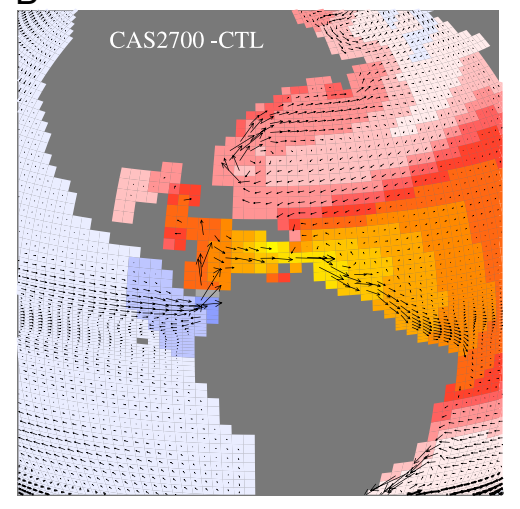

D

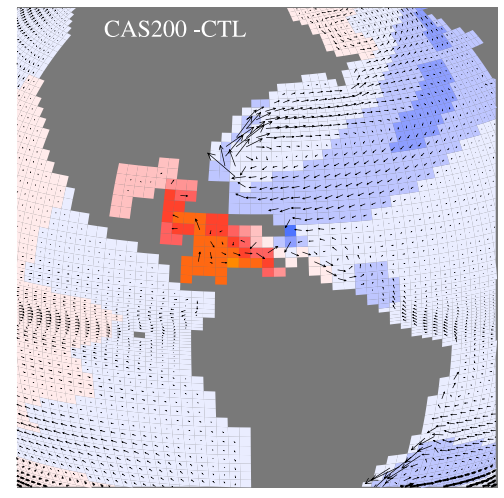

C

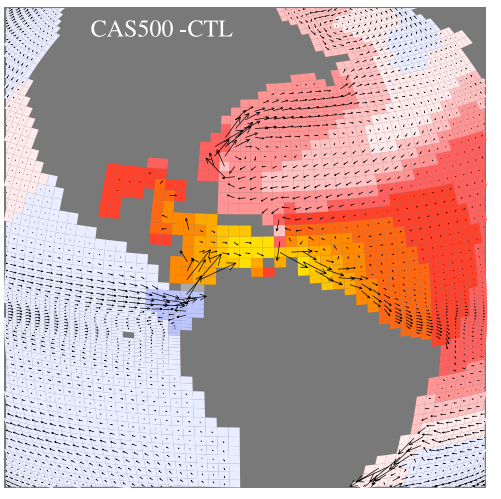

$\stackrel{0.1 \mathrm{~m} / \mathrm{s}}{\longrightarrow}$

E

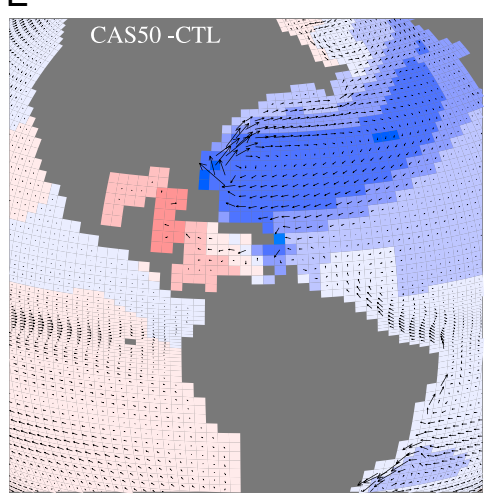

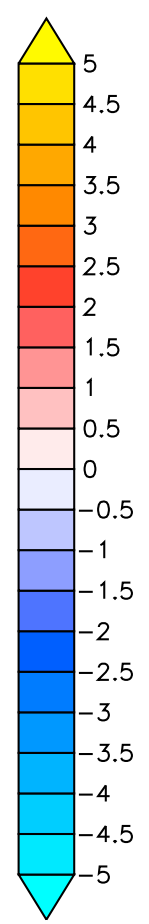

4.5

3.5

5

2

\section{,}

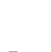

.5

.5

Figure 6. (a) Simulated $\varepsilon_{\mathrm{Nd}}$ at $500 \mathrm{~m}$ depth for the CTL experiment. (b-e) Simulated differences in $\varepsilon_{\mathrm{Nd}}$ at $500 \mathrm{~m}$ depth between open seaway experiments and CTL for CAS2700-CTL (Figure 6b), CAS500-CTL (Figure 6c), CAS200-CTL (Figure 6d), and CAS50-CTL (Figure 6e).

local vertical mixing would only slightly affect the $\varepsilon_{\mathrm{Nd}}$ values, we consider $\varepsilon_{\mathrm{Nd}}$ at $500 \mathrm{~m}$ (depth where interoceanic exchanges are well represented) for the rest of the discussion.

Simulated $\varepsilon_{\mathrm{Nd}}$ values show an overall increase in the Caribbean with an open-isthmus (Figure $5 \mathrm{c}$ ). These higher values are explained by the influence of Pacific subsurface inflow illustrated earlier. The EUC that propagates into the Caribbean originates in the western part of the Pacific basin [Grasse et al., 2012; Grenier et al., 2011, 2013], where volcanic margins imprint very high values to bottom waters [Arsouze et al., 2007; Lacan and Jeandel, 2001]. Before entering the CAS, this water passes over Colombian margins that are also very positive (Figure 1). Considering the simulated horizontal dynamics, Caribbean waters are driven toward more positive values by the inflow of positive Pacific waters. In CAS2700, the $\varepsilon_{\mathrm{Nd}}$ increase affects the whole Caribbean down to $1000 \mathrm{~m}$. At the lower limit of the thermocline $(500 \mathrm{~m})$, CAS2700 and CAS500 show a 3.5 


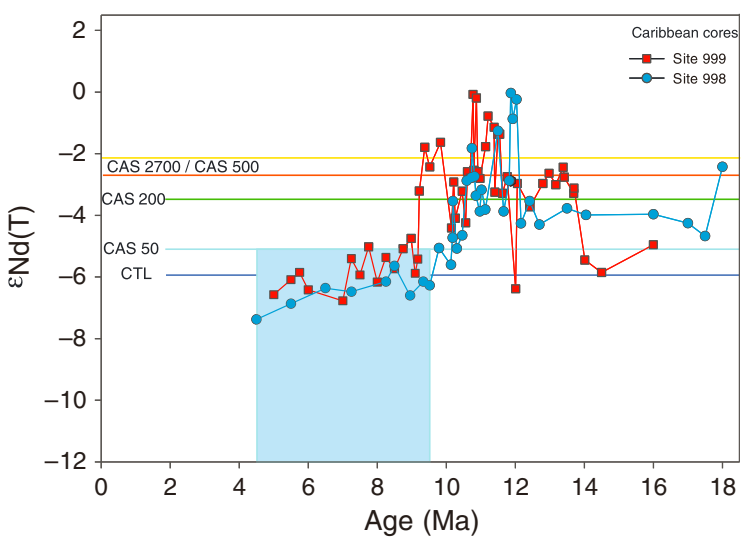

Figure 7. Simulated $\varepsilon_{\mathrm{Nd}}$ for the five experiments compared to published Caribbean data [Newkirk and Martin, 2009]. The blue-shaded area highlights the period when measured values for both ODP sites drop below simulated values for a $50 \mathrm{~m}$ sill. $\varepsilon$ units (up to 5 locally) increase relative to CTL (Figures $6 \mathrm{~b}$ and $6 \mathrm{c}$ ), whereas CAS200 and CAS50 show only 2.5 and $1 \varepsilon$ units increases (Figures $6 \mathrm{~d}$ and $6 \mathrm{e}$ ), respectively, suggesting a nonlinear relationship between seaway depth and Caribbean $\varepsilon_{\mathrm{Nd}}$. This result is produced by the response of Pacific input to CAS shoaling. For the four open-isthmus experiments there are no significant changes in $\varepsilon_{\mathrm{Nd}}$ patterns in the tropical Pacific, which is consistent with the stability of eastern tropical Pacific dynamics with an open CAS.

\section{Discussion}

\subsection{CAS Configuration and Onset of the AMOC}

Since the pioneer modeling work of Maier-Reimer and collaborators [Maier-Reimer et al., 1990], consequences of an open CAS on climate have been repeatedly tested with a wide range of climate models. As mentioned earlier, most studies show that an open CAS results in a decrease of the AMOC, with declines ranging from 2 to $16 \mathrm{~Sv}$. Although these numerical experiments have improved our understanding of ocean dynamics associated with an open CAS, the variety of models used and the fact that those that applied geological constraints on the width of the CAS through time [Herold et al., 2012; von der Heydt and Dijkstra, 2005, 2006] were carried out before the new data from Montes et al. [2012a], limit the ability of those models to determine the timing of CAS constriction and the critical width and depth required for onset of AMOC.

Amongst fully coupled GCM studies [Herold et al., 2012; Lunt et al., 2008; Motoi et al., 2005; Steph et al., 2006; von der Heydt and Dijkstra, 2005, 2006], Steph et al. [2006] have shown that a narrow ( 200 km) seaway allows an eastward water transport of only $12 \mathrm{~Sv}$ that does not provoke a collapse of the AMOC. Comparison with the present study highlights the importance of the CAS configuration on ocean circulation. In Steph et al. [2006], with a narrow CAS set at $10^{\circ} \mathrm{N}$ and oriented zonally (i.e., allowing zonal throughflow), Pacific waters that enter the Caribbean originate farther north than in our simulations and therefore are more saline. As a result, the drop in subsurface salinity linked to CAS opening barely reaches 0.5 practical salinity unit (psu) in the tropical Atlantic [see Steph et al., 2006, Figure 2] and the AMOC is only reduced by 2 Sv. In our study, the CAS is set at $8^{\circ} \mathrm{N}$, oriented to allow meridional water fluxes, and is $400 \mathrm{~km}$ wide. This configuration allows (i) the escape of Atlantic surface salty waters into the Pacific ( 7 Sv), and (ii) input of fresher waters from the EUC and western equatorial coast of South America into the Caribbean and tropical Atlantic ( 14 Sv). The consequence of this circulation pattern is a 2 psu decrease of subsurface salinity in the subtropical Atlantic, enough to prevent advection of dense water to higher latitudes and efficient onset of the AMOC.

These differences also indicate that the CAS width that sets up the onset of a modern AMOC conditions is likely narrower than $400 \mathrm{~km}$. While simulations with higher resolution are necessary to assess the precise width/depth combination that triggers the onset of a strong AMOC, our simulations are consistent with proxies indicating the onset of a proto-North Atlantic Deep Water at $\sim 12 \mathrm{Ma}$ [Lear et al., 2003; Poore et al., 2006] and geological evidence of significant constriction of the CAS by the late Miocene ( 12-10 Ma) [Montes et al., 2012a, Coates et al., 2004; Farris et al., 2011, Duque-Caro, 1990], thereby underscoring the importance of constriction of the CAS as a driver of AMOC, consistent with most previous modeling studies.

\subsection{Simulated $\varepsilon_{\mathrm{Nd}}$ and Constraints on the Timing of CAS Shoaling}

The $\varepsilon_{\mathrm{Nd}}$ measured on fossil fish teeth from Ocean Drilling Program (ODP) sites in the Caribbean exhibit values ranging from -5 to 0 between $18 \mathrm{Ma}$ and $11 \mathrm{Ma}$ (Figure 7), suggesting flow of intermediate waters from the Pacific into the Caribbean at that time [Newkirk and Martin, 2009]. From 10 to $4 \mathrm{Ma}, \mathrm{Nd}$ isotopes shift toward more negative values, a decrease interpreted as a diminishing influence of Pacific waters as the seaway shoaled. Our simulations confirm that Pacific waters enter the Caribbean with an open isthmus, and that the shoaling of the isthmus leads to a decrease in $\varepsilon_{\mathrm{Nd}}$ values. With modeled values of approximately $-2.5 \varepsilon_{\mathrm{Nd}}$ 
units at $500 \mathrm{~m}$, no significant differences are observed amongst experiments with deep (2700 m) and intermediate $(500 \mathrm{~m})$ sills. Interestingly, reconstructed Miocene values from sites 998 and 999 are less radiogenic than these values with the exception of several radiogenic spikes between 10 and $12 \mathrm{Ma}$, (Figure 7). One interpretation of this observation is that the CAS shoaled above $500 \mathrm{~m}$ before $18 \mathrm{Ma}$. Figure 7 also shows that by 9-10 Ma, measured $\varepsilon_{\mathrm{Nd}}$ values from [Newkirk and Martin, 2009] drop below values simulated for a $50 \mathrm{~m}$ sill. This result implies that there were only shallow-water connections through the CAS at that time, in line with the new geological data suggesting near-closure of the CAS by the late Miocene [Montes et al., 2012a]. These interpretations need to be evaluated carefully and tested by further modeling studies with finer resolution, since a positive bias in our model could easily shift our constraints on CAS shoaling toward younger ages. However, even with a 2 unit positive bias (which is reasonable considering model-data differences on Figure 5), simulated values for a $200 \mathrm{~m}$ sill are still higher than most of the recorded values for the late Miocene, supporting a shallow CAS by that time.

Lastly, the simulated stability of $\varepsilon_{\text {Nd }}$ values in the eastern tropical Pacific (Figure 6) is consistent with published records that show very little variation in $\varepsilon_{N d}$ during the Miocene [Newkirk and Martin, 2009]. This is clearly explained by the absence of Atlantic to Pacific throughflow of intermediate and deep waters at that time.

\section{Conclusions}

For the first time, simulations of Nd isotopes forced by a fully coupled GCM are presented to investigate the oceanic impact of shoaling and closure of the CAS. We show that a $400 \mathrm{~km}$ strait set at $8^{\circ} \mathrm{N}$ is consistent with a weak oceanic meridional transport in the Atlantic and with the latest evidence for a narrow seaway since the early Miocene. Our simulations illustrate that the relationship between water fluxes into the Caribbean and seaway depth is nonlinear and that a subtle balance between Panama and Antilles gateways determines the main source for water masses in the Caribbean. Simulated $\varepsilon_{\mathrm{Nd}}$ values show that the seaway depth determines Caribbean subsurface isotopic compositions A first order comparison of simulated $\varepsilon_{\mathrm{Nd}}$ with published data from the Caribbean helps constrain the timing of CAS shoaling. We suggest that by the late Miocene, most of the sill was uplifted above $200 \mathrm{~m}$, but even at that depth there was subsurface inflow from the Pacific into the Caribbean. We acknowledge that these model-derived constraints on the timing of the CAS are sensitive to model uncertainties. Our model has two primary sources of uncertainty, which are linked to the rather coarse $\left(2^{\circ}\right)$ resolution and to margin $\varepsilon_{\mathrm{Nd}}$ values. Uncertainties about the evolution of these margin values throughout the Cenozoic also exist, and future work could be better constrained by new data on margin values through time, as well as high resolution modeling to improve representation of Caribbean subbasins and processes linked to sill overflow. Ultimately, tests with narrower seaway openings would provide new information concerning the exact thresholds driving the onset of AMOC.

Acknowledgments

We thank Martin Frank and an anonymous reviewer for their constructive reviews. The authors also thank Olivier Marti for helping design the boundary conditions of the simulations and Didier Swingedouw for fruitful discussion of our results. Figures have been designed with FAST package for Ferret, developed by Patrick Brockmann at LSCE. This project was supported by Panama Canal Authority contract SAA-199520-KRP; Mark Tupper; Senacyt grants SUM-07001 and EST010-080 A; U.S. National Science Foundation (NSF) grant 0966884 (OISE, EAR, DRL); NSF EAR 0824299; National Geographic; Smithsonian Institution; and Ricardo Perez S.A.

\section{References}

Arsouze, T., J. C. Dutay, F. Lacan, and C. Jeandel (2007), Modeling the neodymium isotopic composition with a global ocean circulation model, Chem. Geol., 239(1), 165-177.

Arsouze, T., J. Dutay, M. Kageyama, F. Lacan, R. Alkama, O. Marti, and C. Jeandel (2008), A modeling sensitivity study of the influence of the Atlantic meridional overturning circulation on neodymium isotopic composition at the Last Glacial Maximum, Clim. Past, 4(3), $191-203$.

Arsouze, T., J. Dutay, F. Lacan, and C. Jeandel (2009), Reconstructing the Nd oceanic cycle using a coupled dynamical- biogeochemical model, Biogeosciences, 6(12), 2829-2846.

Arzel, O., T. Fichefet, and H. Goosse (2006), Sea ice evolution over the 20th and 21st centuries as simulated by current AOGCMs, Ocean Modell., 12(3), 401-415.

Blanke, B., and P. Delecluse (1993), Variability of the tropical Atlantic Ocean simulated by a general circulation model with two different mixed-layer physics, J. Phys. Oceanogr., 23(7), 1363-1388.

Boillot, G., and C. Coulon (1998), La déchirure continentale et l'ouverture océanique -- Géologie des Marges Passives, Gordon and Breach Science Publishers, Paris.

Braconnot, P., B. Otto-Bliesner, S. Harrison, S. Joussaume, J. Y. Peterchmitt, A. Abe-Ouchi, M. Crucifix, E. Driesschaert, T. Fichefet, and C. Hewitt (2007), Results of PMIP2 coupled simulations of the Mid-Holocene and Last Glacial Maximum,ÄiPart 1: Experiments and large-scale features, Clim. Past, 3(2), 261-277.

Butzin, M., G. Lohmann, and T. Bickert (2011), Miocene ocean circulation inferred from marine carbon cycle modeling combined with benthic isotope records, Paleoceanography, 26, PA1203, doi:10.1029/2009PA001901.

Cane, M. A., and P. Molnar (2001), Closing of the Indonesian seaway as a precursor to east African aridification around 3-4 million years ago, Nature, 411 (6834), 157-162.

Coates, A. G., L. S. Collins, M. P. Aubry, and W. A. Berggren (2004), The geology of the Darien, Panama, and the late Miocene-Pliocene collision of the Panama arc with northwestern South America, Geol. Soc. Am. Bull., 116(11-12), 1327-1344.

Coates, A. G., and R. F. Stallard (2013), How old is the isthmus of Panama?, Bull. Mar. Sci., 89(3), 801-814.

Dijkstra, H. A., and J. Neelin (1995), Ocean-atmosphere interaction and the tropical climatology. Part I: The dangers of flux correction, J. Clim., $8,1325-1342$. 
Duque-Caro, H. (1990), Neogene stratigraphy, paleoceanography and paleobiogeography in northwest South America and the evolution of the Panama Seaway, Palaeogeogr. Palaeoclimatol. Palaeoecol., 77(3), 203-234.

Farris, D. W., C. Jaramillo, G. Bayona, S. A. Restrepo-Moreno, C. Montes, A. Cardona, A. Mora, R. J. Speakman, M. D. Glascock, and V. Valencia (2011), Fracturing of the Panamanian Isthmus during initial collision with South America, Geology, 39(11), $1007-1010$.

Fedorov, A., C. Brierley, K. Lawrence, Z. Liu, P. Dekens, and A. Ravelo (2013), Patterns and mechanisms of early Pliocene warmth, Nature, 496(7443), 43-49.

Frank, M. (2002), Radiogenic isotopes: Tracers of past ocean circulation and erosional input, Rev. Geophys., 40(1), 1001, doi: 10.1029/ 2000RG000094.

Frank, M., B. C. Reynolds, and R. Keith O'Nions (1999), Nd and Pb isotopes in Atlantic and Pacific water masses before and after closure of the Panama gateway, Geology, 27(12), 1147.

Frank, M., H. Marbler, A. Koschinsky, T. van de Flierdt, V. Klemm, M. Gutjahr, A. Halliday, P. Kubik, and P. Halbach (2006), Submarine hydrothermal venting related to volcanism in the Lesser Antilles: Evidence from ferromanganese precipitates, Geochem. Geophys. Geosyst., 7, Q04010, doi: 10.1029/2005GC001140.

Gent, P. R., and J. C. McWilliams (1990), Isopycnal mixing in ocean circulation models, J. Phys. Oceanogr., 20(1), $150-155$.

Grasse, P., T. Stichel, R. Stumpf, L. Stramma, and M. Frank (2012), The distribution of neodymium isotopes and concentrations in the Eastern Equatorial Pacific: Water mass advection versus particle exchange, Earth Planet. Sci. Lett., 353, 198-207.

Grenier, M., S. Cravatte, B. Blanke, C. Menkes, A. Koch-Larrouy, F. Durand, A. Melet, and C. Jeandel (2011), From the western boundary currents to the Pacific Equatorial Undercurrent: Modeled pathways and water mass evolutions, J. Geophys. Res., 116, C12044, doi:10.1029/2011JC007477.

Grenier, M., C. Jeandel, F. Lacan, D. Vance, C. Venchiarutti, A. Cros, and S. Cravatte (2013), From the subtropics to the central equatorial Pacific Ocean: Neodymium isotopic composition and rare earth element concentration variations, J. Geophys. Res. Oceans, 118, doi:10.1029/ $2012 J C 008239$.

Griffies, S. M., C. Böning, F. O. Bryan, E. P. Chassignet, R. Gerdes, H. Hasumi, A. Hirst, A.-M. Treguier, and D. Webb (2000), Developments in ocean climate modelling, Ocean Modell., 2(3), 123-192.

Hall, R., and M. Wilson (2000), Neogene sutures in eastern Indonesia, J. Asian Earth Sci., 18(6), 781-808.

Harris, R. (1991), Temporal distribution of strain in the active Banda orogen: A reconciliation of rival hypotheses, J. Southeast Asian Earth Sci., 6(3), 373-386.

Herold, N., M. Huber, R. Müller, and M. Seton (2012), Modeling the Miocene climatic optimum: Ocean circulation, Paleoceanography, 27, PA1209, doi:10.1029/2010PA002041.

Hourdin, F., et al. (2006), The LMDZ4 general circulation model: Climate performance and sensitivity to parametrized physics with emphasis on tropical convection, Clim. Dyn., 27(7-8), 787-813.

Jeandel, C., T. Arsouze, F. Lacan, P. Techine, and J. C. Dutay (2007), Isotopic Nd compositions and concentrations of the lithogenic inputs into the ocean: A compilation, with an emphasis on the margins, Chem. Geol., 239(1), 156-164.

Jochum, M., B. Fox-Kemper, P. H. Molnar, and C. Shields (2009), Differences in the Indonesian seaway in a coupled climate model and their relevance to Pliocene climate and El Niño, Paleoceanography, 24, PA1212, doi:10.1029/2008PA001678.

Johns, W. E., T. L. Townsend, D. M. Fratantoni, and W. D. Wilson (2002), On the Atlantic inflow to the Caribbean Sea, Deep Sea Res., Part I, 49(2), 211-243.

Jones, K. M., S. P. Khatiwala, S. L. Goldstein, S. R. Hemming, and T. van de Flierdt (2008), Modeling the distribution of Nd isotopes in the oceans using an ocean general circulation model, Earth Planet. Sci. Lett., 272(3), 610-619.

Kirby, M. X., and B. MacFadden (2005), Was southern Central America an archipelago or a peninsula in the middle Miocene? A test using landmammal body size, Palaeogeogr. Palaeoclimatol. Palaeoecol., 228(3), 193-202.

Klocker, A., M. Prange, and M. Schulz (2005), Testing the influence of the Central American Seaway on orbitally forced Northern Hemisphere glaciation, Geophys. Res. Lett., 32, L03703, doi:10.1029/2004GL021564.

Krinner, G. (2005), A dynamic global vegetation model for studies of the coupled atmosphere-biosphere system, Global Biogeochem. Cycles, 19, GB1015, doi:10.1029/2003GB002199.

Lacan, F., and C. Jeandel (2001), Tracing Papua New Guinea imprint on the central Equatorial Pacific Ocean using neodymium isotopic compositions and rare earth element patterns, Earth Planet. Sci. Lett., 186(3), 497-512.

Lacan, F., K. Tachikawa, and C. Jeandel (2012), Neodymium isotopic composition of the oceans: A compilation of seawater data, Chem. Geol., 300-301, 177-184

Lear, C. H., Y. Rosenthal, and J. D. Wright (2003), The closing of a seaway: ocean water masses and global climate change, Earth Planet. Sci. Lett., 210(3), 425-436.

Leigh, E. G., A. O'Dea, and G. J. Vermeij (2013), Historical biogeography of the Isthmus of Panama, Biol. Rev., doi:10.1111/brv.12048.

Lunt, D. J., P. J. Valdes, A. Haywood, and I. C. Rutt (2008), Closure of the Panama Seaway during the Pliocene: implications for climate and Northern Hemisphere glaciation, Clim. Dyn., 30(1), 1-18.

MacFadden, B. J. (2006), Extinct mammalian biodiversity of the ancient New World tropics, Trends Ecol Evol, 21(3), 157-165.

Madec, G., and M. Imbard (1996), A global ocean mesh to overcome the North Pole singularity, Clim. Dyn., 12(6), $381-388$.

Maier-Reimer, E., U. Mikolajewicz, and T. Crowley (1990), Ocean general circulation model sensitivity experiment with an open Central American Isthmus, Paleoceanography, 5(3), 349-366.

Marti, O., et al. (2009), Key features of the IPSL ocean atmosphere model and its sensitivity to atmospheric resolution, Clim. Dyn., 34(1), 1-26.

Mikolajewicz, U., and T. J. Crowley (1997), Response of a coupled ocean/energy balance model to restricted flow through the central American isthmus, Paleoceanography, 12(3), 429-441.

Mikolajewicz, U., E. Maier-Reimer, T. J. Crowley, and K. Y. Kim (1993), Effect of Drake and Panamanian gateways on the circulation of an ocean model, Paleoceanography, 8(4), 409-426.

Molnar, P. (2008), Closing of the Central American Seaway and the Ice Age: A critical review, Paleoceanography, 23, PA2201, doi:10.1029/ 2007 PA001574.

Montes, C., G. Bayona, A. Cardona, D. Buchs, C. Silva, S. Moron, N. Hoyos, D. Ramirez, C. Jaramillo, and V. Valencia (2012a), Arc-Continent Collision and Orocline Formation: Closing of the Central American Seaway, J. Geophys. Res., 117, B04105, doi:10.1029/2011JB008959.

Montes, C., et al. (2012b), Evidence for middle Eocene and younger land emergence in central Panama: Implications for Isthmus closure, Geol. Soc. Am. Bull., 124(5-6), 780-799.

Motoi, T., W. L. Chan, S. Minobe, and H. Sumata (2005), North Pacific halocline and cold climate induced by Panamanian Gateway closure in a coupled ocean-atmosphere GCM, Geophys. Res. Lett., 32, L10618, doi:10.1029/2005GL022844.

Murdock, T. Q., A. J. Weaver, and A. F. Fanning (1997), Paleoclimatic response of the closing of the Isthmus of Panama in a coupled oceanatmosphere model, Geophys. Res. Lett., 24(3), 253-256. 
Newkirk, D. R., and E. E. Martin (2009), Circulation through the Central American Seaway during the Miocene carbonate crash, Geology, 37(1), 87-90. Nisancioglu, K. H., M. E. Raymo, and P. H. Stone (2003), Reorganization of Miocene deep water circulation in response to the shoaling of the Central American Seaway, Paleoceanography, 18(1), 1006, doi: 10.1029/2002PA000767.

Pennington, R. T., and C. W. Dick (2004), The role of immigrants in the assembly of the South American rainforest tree flora, Philos. Trans. $R$. Soc., B Biological Sciences, 359(1450), 1611-1622.

Poore, H., R. Samworth, N. White, S. Jones, and I. McCave (2006), Neogene overflow of northern component water at the Greenland-Scotland Ridge, Geochem. Geophys. Geosyst., 7, Q06010, doi: 10.1029/2005GC001085.

Prange, M., and M. Schulz (2004), A coastal upwelling seesaw in the Atlantic Ocean as a result of the closure of the Central American Seaway, Geophys. Res. Lett., 31, L17207, doi:10.1029/2004GL020073.

Rempfer, J., T. F. Stocker, F. Joos, J.-C. Dutay, and M. Siddall (2011), Modelling Nd-isotopes with a coarse resolution ocean circulation model: Sensitivities to model parameters and source/sink distributions, Geochim. Cosmochim. Acta, 75(20), 5927-5950.

Reynolds, B., M. Frank, and R. O'Nions (1999), Nd-and Pb-isotope time series from Atlantic ferromanganese crusts: implications for changes in provenance and paleocirculation over the last 8 Myr, Earth Planet. Sci. Lett., 173(4), 381-396.

Roullet, G., and G. Madec (2000), Salt conservation, free surface, and varying levels: A new formulation for ocean general circulation models, J. Geophys. Res., 105(C10), 23,927-23,942.

Schneider, B., and A. Schmittner (2006), Simulating the impact of the Panamanian seaway closure on ocean circulation, marine productivity and nutrient cycling, Earth Planet. Sci. Lett., 246(3-4), 367-380.

Schneider, B., M. Latif, and A. Schmittner (2007), Evaluation of different methods to assess model projections of the future evolution of the Atlantic meridional overturning circulation, J. Clim., 20(10), 2121-2132.

Siddall, M., S. Khatiwala, T. van de Flierdt, K. Jones, S. L. Goldstein, S. Hemming, and R. F. Anderson (2008), Towards explaining the Nd paradox using reversible scavenging in an ocean general circulation model, Earth Planet. Sci. Lett., 274(3), 448-461.

Steph, S., R. Tiedemann, M. Prange, J. Groeneveld, D. Nürnberg, L. Reuning, M. Schulz, and G. H. Haug (2006), Changes in Caribbean surface hydrography during the Pliocene shoaling of the Central American Seaway, Paleoceanography, 21, PA4221, doi:10.1029/2004PA001092.

Steph, S., R. Tiedemann, M. Prange, J. Groeneveld, M. Schulz, A. Timmermann, D. Nürnberg, C. Rühlemann, C. Saukel, and G. H. Haug (2010), Early Pliocene increase in thermohaline overturning: A precondition for the development of the modern equatorial Pacific cold tongue, Paleoceanography, 25, PA2202, doi:10.1029/2008PA001645.

Stone, R. (2013), Battle for the Americas, Science, 341(6143), 230-233.

Swingedouw, D., P. Braconnot, P. Delecluse, E. Guilyardi, and O. Marti (2007), The impact of global freshwater forcing on the thermohaline circulation: adjustment of North Atlantic convection sites in a CGCM, Clim. Dyn., 28(2), 291-305.

von der Heydt, A., and H. A. Dijkstra (2005), Flow reorganizations in the Panama Seaway: A cause for the demise of Miocene corals?, Geophys. Res. Lett., 32, L02609, doi:10.1029/2004GL020990.

von der Heydt, A., and H. A. Dijkstra (2006), Effect of ocean gateways on the global ocean circulation in the late Oligocene and early Miocene, Paleoceanography, 21, PA1011, doi:10.1029/2005PA001149.

Webb, S. D. (2006), The great American biotic interchange: Patterns and processes, Ann. Mo. Bot. Gard., 93, $245-257$.

Weir, J. T., E. Bermingham, and D. Schluter (2009), The great American biotic interchange in birds, Proc. Natl. Acad. Sci. U. S. A., 106(51), $21,737-21,742$

Zhang, X., et al. (2012), Changes in equatorial Pacific thermocline depth in response to Panamanian seaway closure: Insights from a multimodel study, Earth Planet. Sci. Lett., 317-318, 76-84. 